\title{
Evaluation of Fungicides Applied Via Drip Irrigation for Control of Silver Scurf on Potato in Western Washington
}

\author{
McMoran, D. W. \\ Washington State University Skagit County Extension \\ 11768 Westar Ln, Suite A \\ Burlington, WA 98233 \\ (360) 428-4270 ext. 225 \\ Buller, S. J. \\ Washington State University Skagit County Extension \\ 11768 Westar Ln, Suite A \\ Burlington, WA 98233 \\ (360) 428-4270 ext. 225
}

Received: November 3, 2015 Accepted: November 15, 2015 Published: November 30, 2015

doi:10.5296/jas.v4i1.8646 URL: http://dx.doi.org/10.5296/jas.v4i1.8646

\begin{abstract}
Silver scurf is an economically important disease on potato tubers caused by Helminthosporium solani. Two studies were established near Mount Vernon, WA at Washington State University NWREC on 20 May 2011 and 21 May 2012 in Skagit silt loam soil. Five treatments included: penthiopyrad applied at 45 days after planting (dap), penthiopyrad applied at 60 dap, azoxystrobin (Quadris; 9 oz/acre) applied at 45 dap, and azoxystrobin applied at 60 dap, and a non-treated non-irrigated control. This study did not control for the effect of irrigation, as azoxystrobin- and penthiopyrad-treated plots were drip-irrigated while non-treated plots were not irrigated. The results of this study are therefore limited but do suggest a reduction in silver scurf incidence and severity with no significant impact on yield of potatoes when treated fungicide applied through drip irrigation systems.
\end{abstract}

Keywords: Potatoes, Silver Scurf, Helminthosporium solani, drip irrigation, chemigation

\section{Introduction}

Silver scurf is an economically important disease on potato tubers caused by Helminthosporium solani (Figure 1). Silver scurf is a cosmetic skin blemish of the tuber 


\section{Macrothink}

Journal of Agricultural Studies

ISSN 2166-0379

2016, Vol. 4, No. 1

that results in no internal damage (Powelson, 2008). The pathogen infects the tuber periderm causing lesions that reduce marketability (Errampalli, 2001). Silver Scurf also overwinters in soil, and it has been demonstrated that daughter tubers can become infected by soil borne inoculum (Stevenson, 2004). Fungicides applied through drip irrigation were evaluated for effectiveness in controlling silver scurf and as an alternative to preplant fungicide treatments (maritime, Puget Sound region with mean temps of 58,62 , and $61^{\circ} \mathrm{F}$ and mean precipitation of $1.84,0.86$, and 1.28 in. for Jun, Jul, and Aug respectively).

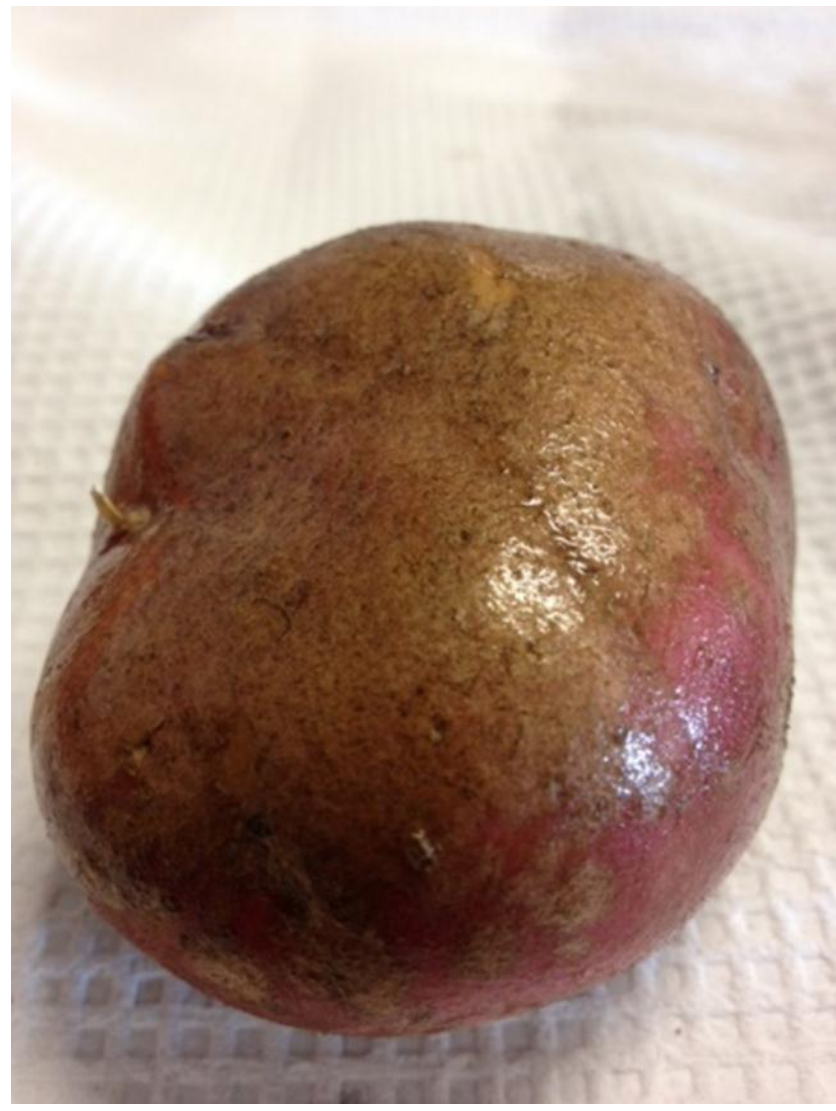

Figure 1. Silver Scurf (Helminthosporium solani) on Chieftian Potato

\section{Methods}

Two studies were established near Mount Vernon, WA at Washington State University NWREC on 20 May 2011 and 21 May 2012 in Skagit silt loam soil. Treatments in both years were arranged as a randomized complete block design with four replications. Treatments were administered via drip irrigation tape. There were two treatments in 2011: penthiopyrad (Vertisan; 24 oz/acre; emulsifiable concentrate) and a non-irrigated, non-treated control. In 2012, five treatments included: penthiopyrad applied at 45 days after planting (dap), penthiopyrad applied at 60 dap, azoxystrobin (Quadris; 9 oz/acre) applied at 45 dap, and azoxystrobin applied at 60 dap, and a non-treated non-irrigated control.

The seed lot had a mean of $100 \%$ incidence (percent of infected tubers per plot) and $79 \%$ severity (percent of tuber surface infected) in 2011, and 70\% incidence and $1.4 \%$ severity in 2012. Plots consisted of 10 -ft rows on 38 -inch centers with a 10 -ft separation between plots. 
In 2011, non-irrigated non-treated and penthiopyrad-treated plots were randomized with other treatments not evaluated for silver scurf and therefore not included in this study. Azoxystrobin and penthiopyrad-treated plots were drip-irrigated (T-Tape US Model 506-12-220; low flow, 16 mm diam., 6 mil wall thickness, 9 in emitter spacing).

\section{Management and Harvest}

The trial was maintained both years with fertilizer and pesticide management practices standard for commercial potato production in the area. Plants were topped (mowed) and then sprayed with Diquat on 25 Aug 2011 and 31 Aug 2012. Harvest took place on 7 Oct 2011 and 10 Oct 2012 to ensure the maximum exposure to silver scurf inoculum in the soil. Each tuber was weighed and graded. Twenty-five potatoes from each plot were evaluated postharvest for 2 weeks, being careful to make sure the samples did not rot before evaluating them for incidence and severity of silver scurf. Data were analyzed with one-way analysis of variance (ANOVA) using PROC MIXED (SAS ver. 9.2). Homogeneity of variance was assessed in all cases using Levene's test in SAS. Treatment means were separated using LSMeans $(P=0.05)$.

\section{Results}

In 2011, control plots had 38\% silver scurf incidence, significantly higher than $4 \%$ for penthiopyrad-treated drip-irrigated plots $(P=0.004)$. Severity of silver scurf also was significantly higher in control plots than penthiopyrad-treated drip-irrigated plots $(6 \% \mathrm{vs}$. $0.8 \%, P=0.0087)$. Total marketable yield of control plots was significantly less than penthiopyrad-treated potatoes (6.24 vs. 6.83 tons/acre; $P=0.03)$. In 2012, incidence of silver scurf again was higher for the control plots (96.92\%) as compared to azoxystrobin-treated at 45 dap and 60 dap $(83.00 \%$ and $81.45 \%$, respectively) and penthiopyrad -treated plots at 45 and 60 dap ( $76 \%$ and $74 \%$, respectively), although treatment differences were not significant (Figure 2). Control plots also had higher silver scurf severity (11\%), as compared to plots treated with azoxystrobin at 45 and 60 dap ( $8 \%$ and $7.5 \%$, respectively) and plots treated with penthiopyrad at 45 and 60 dap (7\% and 6\%, respectively) (Table 1). However, mean severity did not differ significantly among treatments. Although the control plots had lower yields (7.56 tons/acre) than the plots treated with azoxystrobin at 45 and 60 dap (8.35 and 7.92 tons/acre, respectively) and plots treated with penthiopyrad at 45 and 60 dap (8.21 and 8.64 tons/acre, respectively), effect was not significant (Figure 3). This study did not control for the effect of irrigation, as azoxystrobin- and penthiopyrad-treated plots were drip-irrigated while non-treated plots were not irrigated. The results of this study are therefore limited but do suggest a reduction in silver scurf incidence and severity with no significant impact on yield of potatoes when treated fungicide applied through drip irrigation systems. 


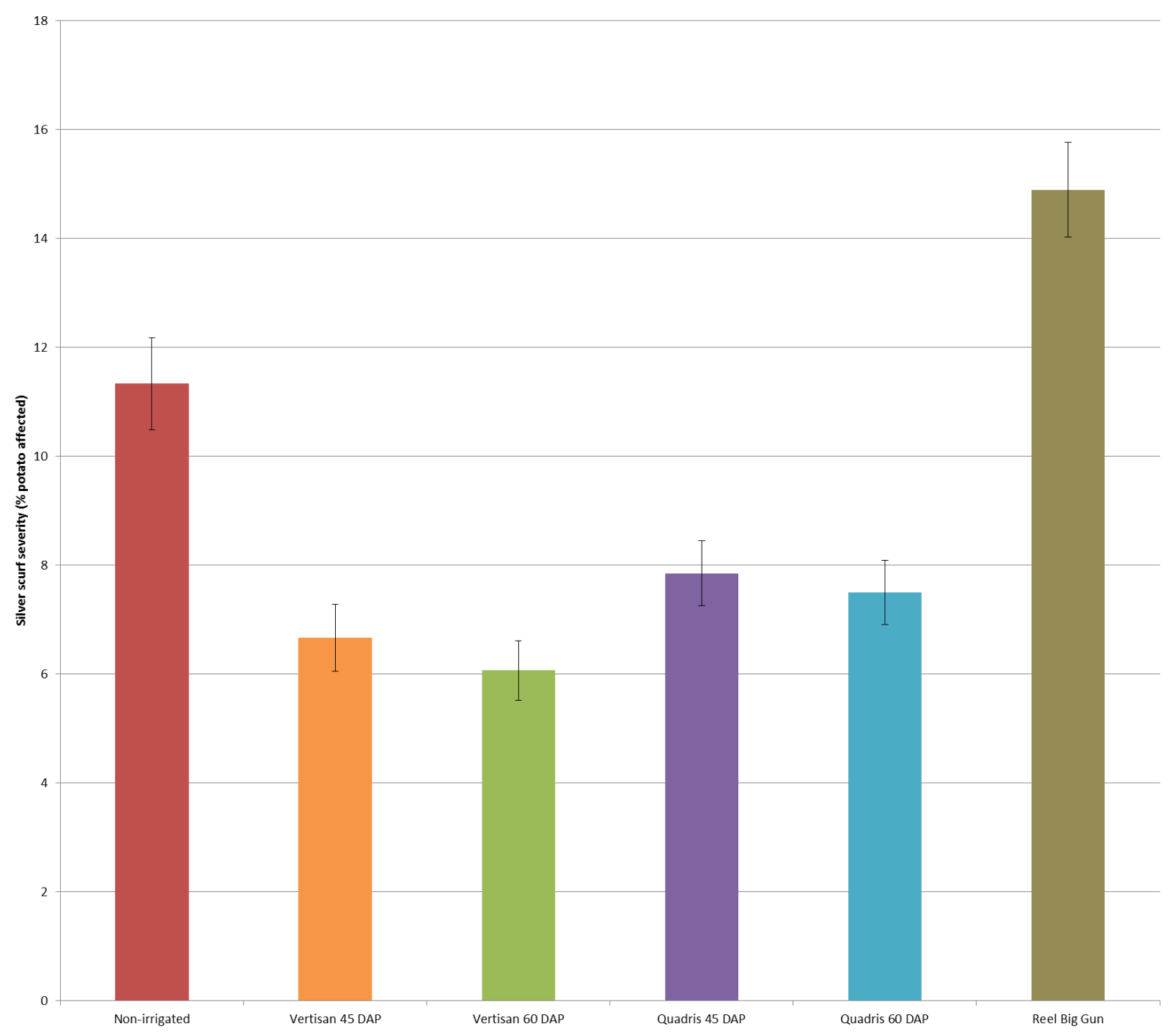

Figure 2. Silver Scurf Severity 2012 Trial

Table 1. Average Silver Scurf Severity 2012 Trial

\begin{tabular}{|l|r|}
\hline Row Labels & Average of \% Silver Scurf \\
\hline Non-irrigated & 11.32916667 \\
\hline Vertisan 45 DAP & 6.666666667 \\
\hline Vertisan 60 DAP & 6.061762422 \\
\hline Quadris 45 DAP & 7.85 \\
\hline Quadris 60 DAP & 7.4993083 \\
\hline Reel Big Gun & 14.89347826 \\
\hline Average Total & 9.050063719 \\
\hline
\end{tabular}




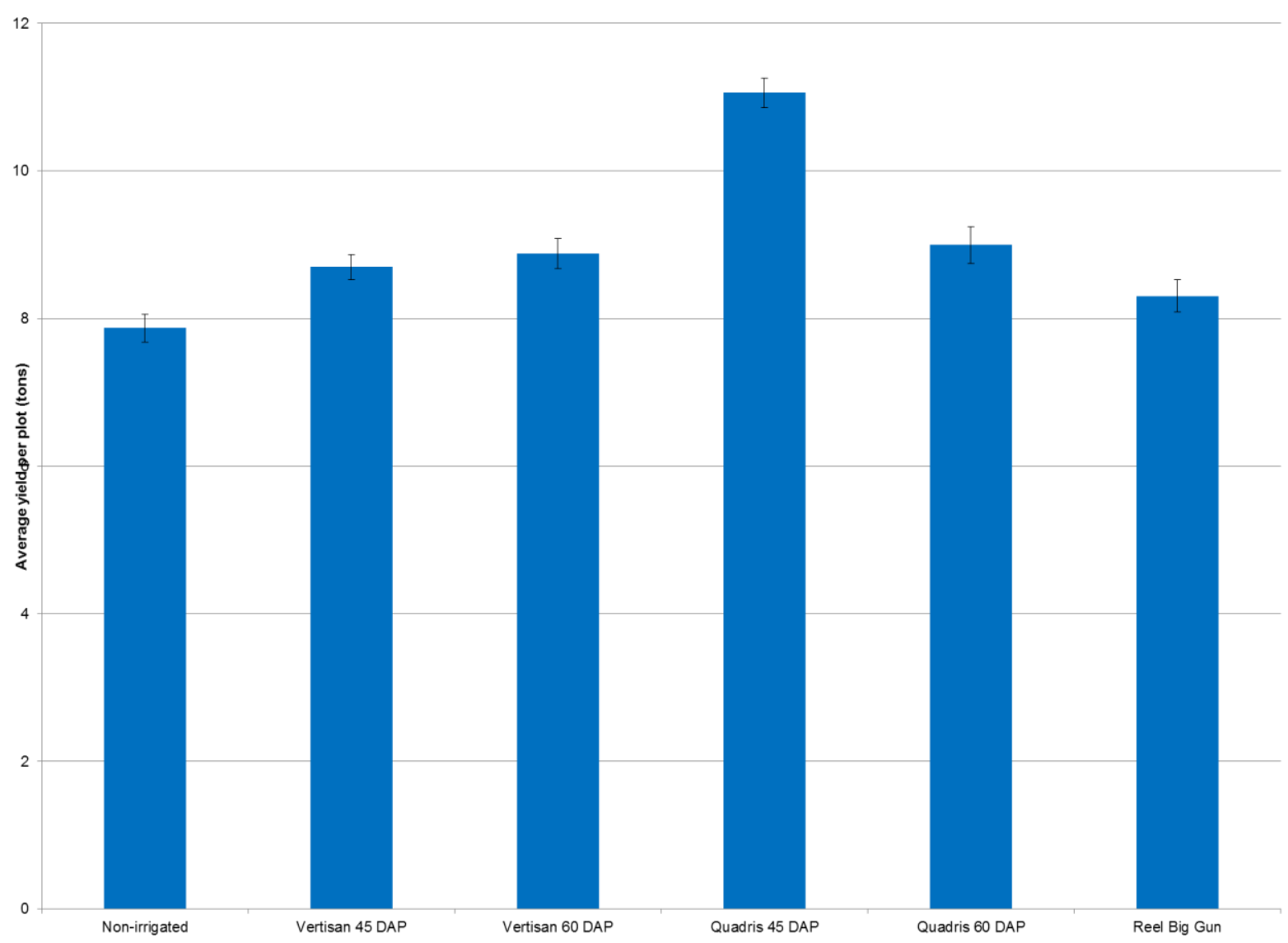

Figure 3. Average Yield 2012 Trial

\section{Acknowledgement}

Research was supported by the Washington State Potato Commission. Thanks to Dr. Debra Inglis, WSU NWREC - Mount Vernon.

\section{References}

Errampalli, D., Saunders, J. M., \& Holley, J. D. (2001). Emergence of silver scurf (Helminthosporium solani) as an economically important disease of potato. Plant Pathology, 50(2), 141-153.

Powelson, M. L., Randall, R.C. (2008). Managing Diseases Caused by Seedborn and Soilborne Fungi and Fungus-Like Pathogens, Potato Health Management, second edition.

Stevenson, W. R., Loria, R., Franc, G. D., Weingartner, D. P. (2004). Compendium of Potato Diseases, second edition.

\section{Glossary}

Dap: days after planting. 


\section{Macrothink}

Journal of Agricultural Studies

ISSN 2166-0379 2016, Vol. 4, No. 1

Silver Scurf: disease affecting the skin of potatoes caused by the fungus Helminthosporium solani.

Silver Scurf Severity: percent of tuber surface infected.

\section{Copyright Disclaimer}

Copyright for this article is retained by the author(s), with first publication rights granted to the journal.

This is an open-access article distributed under the terms and conditions of the Creative Commons Attribution license (http://creativecommons.org/licenses/by/3.0/). 